\title{
INSIGHTS
}

\section{The greatest pediatric meeting ever in French Lick, Indiana?}

\author{
Scott D. Krugman ${ }^{1}$ \\ Pediatric Research (2019) 86:136-137; https://doi.org/10.1038/s41390-019-0355-2
}

The year was 1950, and the location was the historic resort hotel in French Lick, Indiana ${ }^{1}$. Participants of the combined American Pediatric Society (APS) and Society for Pediatric Research (SPR) meeting made their way from coast to coast to the remote but scenic hotel. Granted, only 6 of the 200 or so members came from California, but doctors from as far as Geneva, Switzerland and Puerto Rico came for the proceedings. Unlike the modern Pediatric Academic Societies meeting, which is a large, often overwhelming, mass of research and workshops in a large city convention center, back in the 1940s and 1950s the meetings were more intimate affairs. A small, select number of pediatricians and invited guests would present the latest in pediatric research at a much smaller venue, like a resort or hotel. This was the second time the meeting was held in French Lick, the first being in 1923, and not coincidentally the first year of the Emmett Holt Golf Cup. ${ }^{1}$ Nevertheless, I imagine the historic hotel made for a great backdrop for the parade of notable pediatricians presenting at the meeting.

Day 1 of the 3-day program featured presentations from the SPR. The SPR president Dr. Francis Schwentker opened the program. Only 4 years prior to his untimely death, he was 4 years into his tenure as the chair of pediatrics at the Johns Hopkins Children's Center after succeeding Edwards Park, who was still present in Baltimore and a member of the APS who would be honored 2 years later with the first ever Howland Award. Other Baltimore notaries who presented at the meeting included Helen Taussig (6 years after helping invent the first Blaylock-Taussig shunt for tetralogy of Fallot), who spoke on the clinical diagnosis of Truncus Arteriosus and Pseudo-Truncus Arteriosus, and Lawson Wilkins (the grandfather of pediatric endocrinology), who spoke about the suppression of androgen secretion of cortisone in children with congenital adrenal hyperplasia.

Not surprisingly, many of the presentations highlighted the advances in the blossoming field of infectious diseases. The meeting started with a group of "guests" (non-SPR members) from Boston-future Nobel Prize winners T.H. Weller and John Enders who linked an outbreak of pleurodynia in Boston to Coxsackie virus. The first day continued with presentations from the New York University (NYU) teams of John Osborn and Joe Dancis, describing quantitative measurement of newborn antibody transfer, and Saul Krugman and Robert Ward, evaluating the effect of Triethylene Glycol in reducing nosocomial transmission of measles virus on the infant's ward at Bellevue. Unfortunately, it wasn't that effective. But fortunately, they went on to study other viruses and produce the xclassic Infectious Diseases of Children textbook. While not an infectious disease specialist, the chair of NYU L. Emmett Holt Jr. presented about feeding premature infants.
Other infectious disease giants appeared during the APS program the next few days. On the third day alone, Henry Kempe and Henry Silver, while both were in San Francisco before going to the University of Colorado and became famous for coining the "Battered Child Syndrome," described the infectious nature of exanthem subitum. Then fellow colleague from San Francisco Harold Faber presented on poliovirus excretion, while future Lasker Prize winner and oral polio vaccine developer Albert Sabin from Cincinnati described the presence of anti-poliomyelitis antibodies in breast milk. The session also included the physician in chief at the Children's Hospital of Philadelphia Joseph Stokes Jr., who made observations on the role of intestinal flora on growth.

Not to be left out, early pioneers from nephrology, pulmonology, hematology/oncology, and radiology made presentations throughout the conference. Prominent Harvard names including Louis Diamond, Harry Schwachman, and Sidney Farber made presentations years before they named Schwachman-Diamond Syndrome and had a cancer center named in his honor. An earlycareer Cliff Grullee Jr. (son of the executive secretary and founding member of the American Academy of Pediatrics Cliff Grullee Sr.) presented on using spirometry to measure respiratory function on ventilated children. Thirteen years later he would become Dean at the University of Cincinnati School of Medicine. Charles A. Janeway, 4 years into his 30-year term as chair at Boston Children's Hospital, presented on nephrotic syndrome. Other notable names at the conference included Donovan McCune (after naming McCune Albright syndrome), Victor Najjar (while he was still at Johns Hopkins, 2 years before describing Crigler-Najjar Syndrome), Henry Barnett (one of the founders of pediatric nephrology), and John Caffey (the father of pediatric radiology and first to describe abusive head trauma).

With the large Pediatric Academic Societies meetings of the past 30 years in large convention centers and big cities, it can be hard to "run into" and interact with the pioneers of pediatrics. Clearly, an invitation to the Howland Award dinner can help, but even the young invited pediatricians to the 1950 meeting couldn't help but interact with many of the names that laid the foundation for pediatrics as we know it today. A total of 78 papers were presented over the 3 days. Of those talks, 15 (almost 20\%) featured speakers who would go on to win the Howland Award (the most prestigious pediatric research award presented by the APS since 1952). It is hard to imagine a more concentrated meeting of distinguished pediatricians has ever been held.

\section{ADDITIONAL INFORMATION}

Competing interests: The authors declare no competing interests.

${ }^{1}$ Department of Pediatrics Herman and Walter Samuelson Children's Hospital at Sinai, 2401 West Belvedere Avenue, Baltimore, MD 21215, USA

Correspondence: Scott D. Krugman (skrugman@lifebridgehealth.org)

Received: 13 February 2019 Accepted: 18 February 2019

Published online: 23 February 2019 
The greatest pediatric meeting ever in French Lick, Indiana?

Publisher's note: Springer Nature remains neutral with regard to jurisdictional claims in published maps and institutional affiliations.

\section{REFERENCES}

1. Pearson, H. A. The Centennial History of the American Pediatric Society: 1888-1988 (Yale University Printing Service, New Haven, 1988). 